
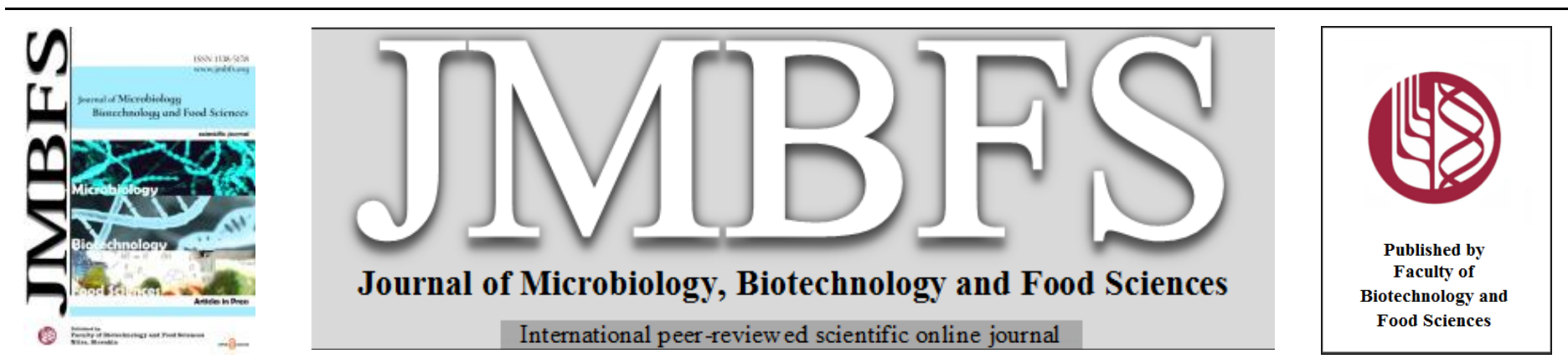

\title{
NOVEL SPECIFIC PRIMERS FOR THE SPECIFIC DETECTION OF FUSARIUM OXYSPORUM F. SP. CUBENSE BASED ON SYBR GREEN REAL-TIME PCR
}

\author{
Nongnid Prachaiboon, Thanwanit Thanyasiriwat, Praphat Kawicha*
}

Address(es):

Plant Pest and Biocontrol Research Unit, Plant Genome Technology Research Unit, Department of Agriculture and Resources, Faculty of Natural Resources and AgroIndustry, Kasetsart University Chalermphrakiat Sakon Nakhon Province Campus, Sakon Nakhon 47000, Thailand.

*Corresponding author: csnppkc@ku.ac.th

https://doi.org/10.55251/jmbfs.4767

\section{ARTICLE INFO}

Received 12. 5. 2021

Revised 12. 8. 2021

Accepted 13. 8. 2021

Published 1. 2. 2022

Regular article open $\partial_{\text {ACCESS }}$

\begin{abstract}
Fusarium oxysporum f. sp. cubense (Foc) is the causal agent of Fusarium wilt of banana worldwide. Foc is transmitted to another banana plantation via an infected banana sucker. A specific and sensitive detection assay could be used for disease-free propagule screening to prevent disease dispersal effectively. In this study, SYBR green-based real-time PCR assay was developed based on novel specific primers targeting the large subunit of RNA polymerase II (RPBI) gene. The partial $R P B 1$ gene was amplified and sequenced from $F o c$ isolate FOC1708 and SK3-2. Regions specific for Foc were identified and used for designing real-time PCR primers. The specificity of the designed primers was evaluated on genomic DNA from Foc isolates and non-target microorganisms. The results showed that the designed primers were specific to only Foc isolates from race 1 and tropical race 4 (TR4). The detection efficiency of the designed primers was compared to other published primers through optimized SYBR green-based real-time PCR assay and nested PCR. The new primers could detect the Foc genomic DNA at a minimum of $5 \mathrm{pg}$ and target pathogen in a symptomless banana sucker. The specificity and sensitivity of the new primers were comparable to the published real-time PCR primers and the nested PCR assay. This developed assay with these novel primers can aid the disease quarantine for effective prevention and control of the Fusarium wilt of banana.
\end{abstract}

Keywords: Banana; Detection; Fusarium; Panama disease; Real-time PCR

\section{INTRODUCTION}

Fusarium wilt of banana (Panama disease) caused by Fusarium oxysporum $\mathrm{f}$. sp cubense $(F o c)$ is one of the most significant threats to banana production (Musa spp.) worldwide (Bentley et al., 1998). Based on the pathogenicity on different banana cultivars, Foc can be divided into races (Stover, 1990), including Foc race 1 , race 2 , race 3 , and race 4 . Foc race 1 occurs worldwide and causes disease on Gros Michel (genome type=AAA) and a range of other cultivars carrying the AAB genome. Foc race 2 causes disease on those race 1 -susceptible cultivars, as well as the hybrid triploid 'Bluggoe' (AAB). Foc race 4 is separated into tropical race 4 (TR4) and subtropical race 4 (STR4). STR4 causes disease in Cavendish in the subtropics, whereas TR4 targets Cavendish under tropical and subtropical conditions (Buddenhagen, 2009).

The disease pathogen infects healthy bananas through their roots and spreads to the upper plant parts and vascular bundles. The pathogen causes leaf yellowing and wilt symptoms by blocking the banana vascular bundle (Ploetz, 2006). As the pathogen is transmitted through vascular tissues, the pathogen can be transmitted to a banana sucker (Stover, 1962; Li et al., 2011). The symptomless infected suckers can be a source of inoculum and cause disease dispersal from farm to farm or between countries (Dita et al., 2018). Therefore, an effective and essential strategy to prevent the disease is to use disease-free propagating materials.

PCR based detection assays including PCR (Li et $\boldsymbol{a l}$., 2012), nested PCR (Prachaiboon et al., 2020), real-time or quantitative PCR (Yang et al., 2015; Lin et al., 2013) were used to detect the Foc from banana propagules before planting or in disease quarantine. Conventional PCR is widely used to detect Foc; however, its sensitivity is lower than nested PCR (Prachaiboon et al., 2020) and real-time PCR (Lin et al., 2013). Additionally, the PCR assay, including nested PCR, requires time and labor to perform the PCR (Schaad and Frederick, 2002). Real-time PCR has been developed to address the limitations of PCR and can be used to quantify pathogen DNA in a plant, water, and soil samples (Matthews et al., 2020)

Most real-time PCR assays developed for Foc detections are mainly based on TaqMan-based systems (Yang et al., 2015; Lin et al., 2016; Aguayo et al.,
2017; Matthews et al., 2020) that provide higher sensitivity than other assays and detect different races in one reaction. However, TaqMan-based detection requires a fluorogenic probe which increases running costs and assay set up. SYBR green-based detection is an optional system comparable to TaqMan-based detection in performance and quality (Tajadini et al., 2014). In addition, SYBR green-based real-time PCR is relatively cost-benefit and easy to use and technically based on binding the fluorescent dye to double-stranded deoxyribonucleic acid (dsDNA) (Tajadini et al., 2014). Therefore, this research aimed to develop a SYBR green-based real-time PCR assay for the detection of Foc. This study designed new primers targeting the largest subunit of RNA polymerase II $(R P B 1)$ gene. The sequence of the $R P B 1$ gene has been used for phylogenetic analysis of Fusarium species (O'Donnell et al., 2013; Czislowski et al., 2018). The RPB1 gene reflects the horizontal transmission of one family of effectors, the Secreted In Xylem (SIX) genes and could be a potential source to improve the Foc diagnostic (Czislowski et al., 2018).

\section{MATERIAL AND METHODS}

\section{Fungal isolates and mycelial DNA extraction}

Foc race 1 isolate FOC1708, used as a reference strain, was provided by the Department of Agriculture, Thailand. Besides, Foc race 1 isolate SK3-2 and NP1-4 were collected from infected bananas from Sakon Nakhon and Nakhon Phanom province, Thailand, and were identified as Foc based on microconidia, macroconidia, and chlamydospore characteristics (Leslie \& Summerell, 2008), pathogenicity on banana seedling, and PCR assay with Foc race 1 specific primers (Yang et al., 2015). Foc isolates were maintained on potato dextrose agar at $4{ }^{\circ} \mathrm{C}$. Genomic DNA was extracted from mycelia using the Qiagen kit or CTAB method. The DNA concentration was determined using a Thermo Scientific $^{\mathrm{TM}}$ NanoDrop ${ }^{\mathrm{TM}}$ lite spectrophotometer. 


\section{Real-time PCR primer design}

The gene encoding the largest subunit of RNA polymerase II (RPBI) was selected as a target sequence for real-time PCR primer design. Partial RPB1 gene was amplified from Foc isolates FOC1708 and SK3-2 using primers Fa (Hofstetter et al., 2007)/G2R (Benjamin Hall, unpublished data) and $\mathrm{Fa} / \mathrm{R} 8$ reported by O'Donnell $\boldsymbol{e t}$ al. (2010). The PCR reaction contained $0.2 \mu \mathrm{M}$ each primer, $0.2 \mu \mathrm{M}$ dNTPs, $1 \mathrm{X}$ buffer S, $1 \mathrm{U}$ of the Taq polymerase (Vivantis, Malaysia), and $50 \mathrm{ng}$ Foc DNA. The PCR was performed using the following thermocycling conditions: $95{ }^{\circ} \mathrm{C}$ for $5 \mathrm{~min} ; 35$ cycles of $95{ }^{\circ} \mathrm{C}$ for $45 \mathrm{~s}, 55^{\circ} \mathrm{C}$ for $45 \mathrm{~s}$, and $72{ }^{\circ} \mathrm{C}$ for $60 \mathrm{~s}$; and a final extension at $72{ }^{\circ} \mathrm{C}$ for $5 \mathrm{~min}$. The PCR products were purified using BioFact ${ }^{\mathrm{TM}}$ PCR Purification Kit, then were sequenced by Macrogen. Multiple alignments of partial RPB1 sequences from Foc isolate FOC1708, SK3-2, and other Fusarium species derived from the NCBI database were constructed using BioEdit Sequence Alignment Editor (Hall, 1999). Regions specific for Foc were identified. Primers were designed and analyzed using the Primer3 software (Koressaar and Remm, 2007).

\section{SYBR green-based real-time PCR assay}

The real-time PCR assays were performed to amplify the partial $R P B 1$ gene of Foc using SensiFAST ${ }^{\mathrm{TM}}$ SYBR No-ROX Kit (Bioline, UK). The assay was carried in a $10 \mu \mathrm{l}$ volume solution containing 1X SensiFAST SYBR No-Rox Mix, $400 \mathrm{nM}$ forward and reverse primers, and $1 \mu \mathrm{l}$ of purified DNA. The optimized thermocycling conditions were 1 cycle of $95{ }^{\circ} \mathrm{C}$ for 2 min and 30 cycles of $95{ }^{\circ} \mathrm{C}$ for $30 \mathrm{~s}$ and $70{ }^{\circ} \mathrm{C}$ for $30 \mathrm{~s}$, followed by a melting curve analysis program according to the real-time PCR machine instruction. All the reactions were performed in triplicate on the PCRmax Eco 48 real-time PCR system (PCR $\max , \mathrm{UK})$.

\section{The specificity of the assay}

The specificity of the designed primers to detect Foc was evaluated on genomic DNA from Foc race 1 isolates, including FOC1708, SK3-2, NP1-4, and Foc tropical race 4 (TR4) isolate PM-HTS-Fo56, PM-HTS-Fo57, and PM-HTS-Fo58 provided by Associate Professor Dr. Ying-Hong Lin, Department of Plan Medicine, National Pingtung University of Science and Technology. Fusarium oxysprum f. sp. lycopersici ( $\mathrm{Fol}$ ), Trichoderma asperellum, Pestalotiopsis sp. Colletotrichum capsici, C. gloeosporioides, Ralstonia solanacearum, and $R$. syzygii subsp. celebesensis were used in the specificity test. The real-time PCR reaction and thermal cycle condition were followed the above condition.

\section{Sensitivity, standard curve, and amplification efficiency of the assay}

The newly developed real-time PCR primer set's sensitivity was examined by testing a series of $1: 10$ dilutions of the pGEM $^{\circledR}-\mathrm{T}$ Easy vector (Promega Corporation, Madison, WI, USA) containing the partial RPB1 gene (pGEM ${ }^{\circledR}-\mathrm{T}$ $\mathrm{RPB} 1)$ ranging from $10^{7}$ to 10 copies/ $\mu$ l. The obtained quantitation cycle $(\mathrm{Cq})$ values were plotted against the target gene copy number to create a standard curve. Amplification efficiency was calculated using QPCR Standard Curve Slope to Efficiency Calculator available at https://www.chem.agilent.com/store/biocalculators/calcSlopeEfficiency.jsp.

\section{Detection efficiency of the assay}

Detection efficiency of the newly developed real-time PCR primers, RPB11 primer set, targeting the RPB1 gene in genomic DNA of Foc, varied from $50 \mathrm{ng}$ to $0.5 \mathrm{pg}$, was compared with published primers for Foc detection, including realtime PCR primers, Foc1-0422F1/Foc1-0422R1 (Table 1) designed by Yang et al. (2015), and nested PCR primers developed by Prachaiboon et al. (2020). The real-time PCR reaction for primer Foc1-0422F1 and Foc1-0422R1 was the same as the RPB11 primer set, although the thermal cycling differed. The optimized thermocycling conditions for the Foc1-0422 primer set were 1 cycle of $95{ }^{\circ} \mathrm{C}$ for $2 \mathrm{~min}$ and 30 cycles of $95^{\circ} \mathrm{C}$ for $30 \mathrm{~s}$ and $66^{\circ} \mathrm{C}$ for $30 \mathrm{~s}$, followed by a melting curve analysis program. The nested PCR was performed by using primer W1805F and W1805R (Table 1) (Li et al., 2012) for the first round PCR and primer W18051F3 and W18051B3 (Table 1) in the second-round PCR. The PCR reaction contained $0.2 \mu \mathrm{M}$ each primer, $0.2 \mu \mathrm{M}$ dNTPs, $2 \mathrm{mM} \mathrm{MgCl} 2,1 \mathrm{X}$ buffer A, $1 \mathrm{U}$ of the Taq polymerase (Vivantis, Malaysia), and $1 \mu \mathrm{I}$ DNA sample. The first-round PCR was performed using the following thermocycling conditions: 95 ${ }^{\circ} \mathrm{C}$ for $2 \mathrm{~min} ; 30$ cycles of $95{ }^{\circ} \mathrm{C}$ for $30 \mathrm{~s}, 58.4{ }^{\circ} \mathrm{C}$ for $30 \mathrm{~s}$, and $72{ }^{\circ} \mathrm{C}$ for $2 \mathrm{~min}$; and a final extension at $72{ }^{\circ} \mathrm{C}$ for $5 \mathrm{~min}$. The first-round PCR product was diluted at 1:20 then used as a second-round PCR template. The second-round PCR was performed using the following thermocycling conditions: $95{ }^{\circ} \mathrm{C}$ for $2 \mathrm{~min} ; 30$ cycles of $95{ }^{\circ} \mathrm{C}$ for $30 \mathrm{~s}, 63{ }^{\circ} \mathrm{C}$ for $30 \mathrm{~s}$, and $72{ }^{\circ} \mathrm{C}$ for $2 \mathrm{~min}$; and a final extension at $72{ }^{\circ} \mathrm{C}$ for $5 \mathrm{~min}$. The nested PCR products were checked by $1 \%$ agarose gel electrophoresis.

To examine the detection efficiency, novel RPB11F/RPB11R and published Foc1-0422F1/Foc1-0422R1 primers with SYBR green-based real-time PCR assay as well as nested PCR were performed to detect $F o c$ in banana suckers. Ten symptomless banana suckers were collected from Foc infected parent plants Three roots, $1 \mathrm{~cm}$ in length next to the base of a sucker, were sampled from each sucker then the sampling roots were used for DNA extraction by the CTAB method. The detection efficiency using novel RPB11F/RPB11R real-time PCR primers compared with the real-time PCR with primer Foc1-0422F1/Foc10422R1 and the nested PCR. The real-time PCR and nested PCR reaction and thermal cycling conditions were mentioned above.

\section{RESULTS}

\section{The specificity of the real-time PCR primer}

Multiple alignments of partial RPB1 sequences revealed specific regions among Foc isolates but not other Fusarium species (Figure 1). The regions were used to design new real-time PCR primers (RPB11) based on the RPB1 gene, including primer RPB11F and primer RPB11R (Figure 1). Primer sequences were listed in Table 1. For determining the specificity of the designed primers, DNA from Foc, Fusarium species, plant pathogenic fungi, microbes that were probably found in the banana rhizosphere were used for real-time PCR with RPB11 primer set following the real-time PCR reaction described in MATERIAL AND METHODS. The results showed that the PPB11 primer set specifically detected all isolates of Foc race 1 and TR4. However, there was a difference in the Quantification cycle $(\mathrm{Cq})$ and melting temperature $(\mathrm{Tm})$ value between isolates of Foc race 1 and TR4. The RPB11 primer set generated a positive amplification signal for Foc race 1 isolates at $\mathrm{Cq} 13$ to 15 , but the primer showed a positive signal for Foc TR4 isolates at $\mathrm{Cq} 26$ to 28 (Figure 2A). The Tm values of the amplified products of $F o c$ race 1 isolates were $84{ }^{\circ} \mathrm{C}$, but the Foc TR4 isolates were around $84.7-85^{\circ} \mathrm{C}$ (Figure $2 \mathrm{~B}$ ). The RPB 11 primer set did not generate a positive signal for non-target microbes (Table 2).

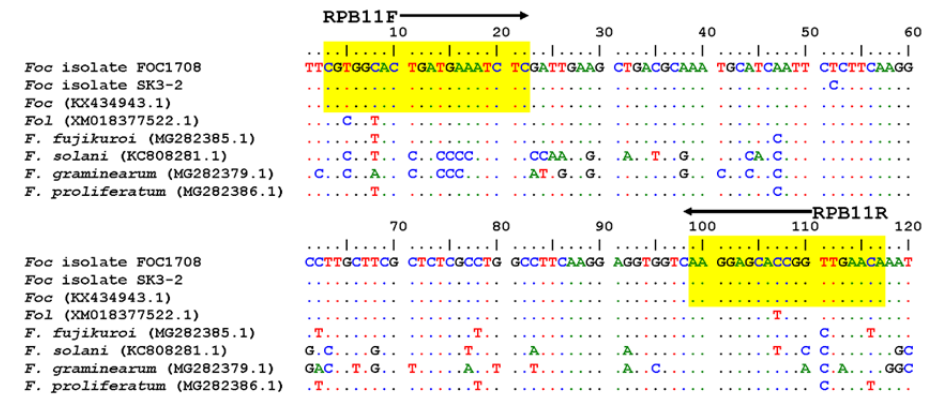

Figure 1 Multiple nucleotide sequence alignment of RPB1 gene from Fusarium oxysporum f. sp. cubense and Fusarium spp.. The sequence of primer RPB11F and RPB11R are highlighted with yellow colour.

Table 1 Sequences of primers used in this study

\begin{tabular}{|c|c|c|c|}
\hline Assay & Primer name & Sequence (5'-3’) & Reference \\
\hline \multirow{3}{*}{$\begin{array}{l}\text { SYBR } \\
\text { green } \\
\text { real-time } \\
\text { PCR }\end{array}$} & RPB11F & CGTGGCACTGATGAAATCTC & This study \\
\hline & RPB11R & TGTTCAACCGGTGCTCCTT & This study \\
\hline & $\begin{array}{l}\text { Foc1-0422F1 } \\
\text { Foc1-0422R1 }\end{array}$ & $\begin{array}{l}\text { AGGTGAGAAATCTGTTGAGTCTCGAT } \\
\text { AACTCCTTCACCAGCCTTTCG }\end{array}$ & $\begin{array}{l}\text { Yang et al. (2015) } \\
\text { Yang } \text { et al. (2015) }\end{array}$ \\
\hline \multirow{2}{*}{$\begin{array}{l}\text { Nested } \\
\text { PCR }\end{array}$} & $\begin{array}{l}\text { W1805F } \\
\text { W1805R }\end{array}$ & $\begin{array}{l}\text { GTTGAGTCTCGATAAACAGCAAT } \\
\text { GACGAGGGGAGATATGGTC }\end{array}$ & $\begin{array}{l}\text { Li et al. (2012) } \\
\text { Li et al. (2012) }\end{array}$ \\
\hline & $\begin{array}{l}\mathrm{W} 18051 \mathrm{~F} 3 \\
\mathrm{~W} 18051 \mathrm{~B} 3\end{array}$ & $\begin{array}{l}\text { CTGGTGAAGGAGTTGTCCG } \\
\text { TTGTGATGTCGGCATGAGAT }\end{array}$ & $\begin{array}{l}\text { Prachaiboon et al. } \mathbf{( 2 0 2 0 )} \\
\text { Prachaiboon } \text { et al. }(\mathbf{2 0 2 0})\end{array}$ \\
\hline
\end{tabular}



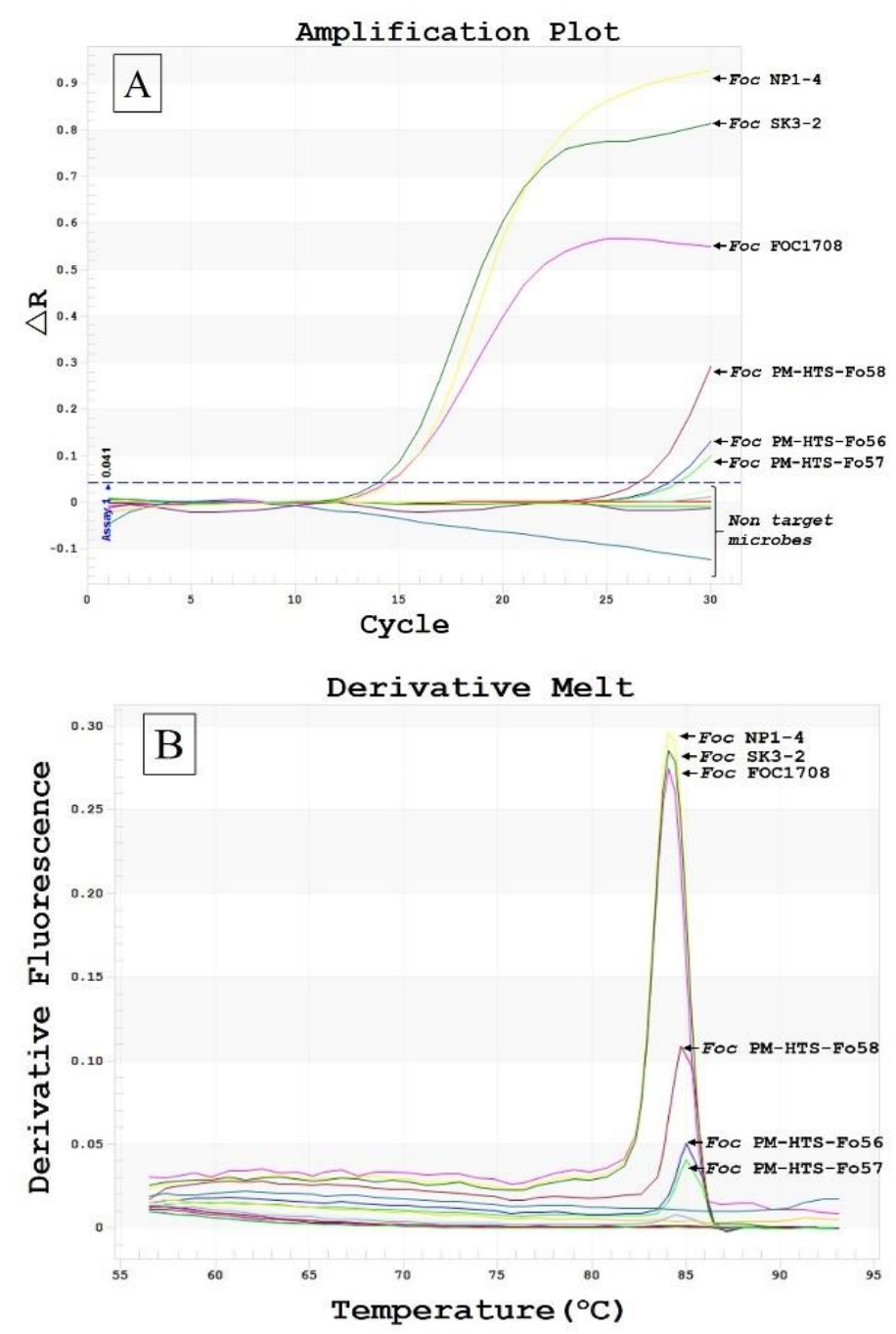

Figure 2 RPB11 specificity test by real-time PCR using genomic DNA of Fusarium oxysporum f. sp. cubense race 1, TR4, and non-target microorganisms (Sample's names are listed in Table 2). A: amplification signal and B: melting temperature.

Table 2 Specificity of the developed real-time PCR assay targeting RPB1 gene

\begin{tabular}{lcc}
\hline Sample name & Cq & Tm $\left({ }^{\circ} \mathbf{C}\right)$ \\
\hline Foc race 1 isolate FOC1708 & $14.94 \pm 0.50$ & $84 \pm 0.17$ \\
Foc race 1 isolate SK3-2 & $13.87 \pm 0.08$ & $84 \pm 0.17$ \\
Foc race 1 isolate NP1-4 & $14.53 \pm 0.07$ & $84 \pm 0.17$ \\
Foc TR4 isolate PM-HTS-Fo56 & $27.93 \pm 0.17$ & $85 \pm 0.30$ \\
Foc TR4 isolate PM-HTS-Fo57 & $28.43 \pm 0.11$ & $85 \pm 0.30$ \\
Foc TR4 isolate PM-HTS-Fo58 & $26.53 \pm 0.10$ & $84.7 \pm 0.3$ \\
Fol isolate Fol101 & - & - \\
Fol isolate Fol401 & - & - \\
Colletotrichum capsici isolate CCC5 & - & - \\
C. gloeosporioides isolate CGC7 & - & - \\
Pestalotiopsis sp. isolate III & - & - \\
Trichoderma asperellum isolate TPK101 & - & - \\
Ralstonia solanacearum isolate 832 & - & - \\
Ralstonia syzygii isolate RM1201 & - & - \\
Negative control & - & - \\
\hline
\end{tabular}

The sensitivity, standard curve, and amplification efficiency of the developed real-time PCR assay

For the sensitivity test, serial dilutions of $\mathrm{pGEM}^{\circledR}$-T Easy vector containing the partial $R P B 1$ gene (pGEM ${ }^{\circledR}-\mathrm{T}-\mathrm{RPB} 1$ ) were used to examine the sensitivity of the real-time PCR assay with RPB11 primer set. The results showed that the assay with $10^{7}$ to $10^{3}$ pGEM ${ }^{\circledR}-\mathrm{T}-\mathrm{RPB} 1$ copies as the templates generated a positive amplification signal, but not with $10^{2}$ pGEM $\mathbb{R}-\mathrm{T}-\mathrm{RPB} 1$ copies (Figure $3 \mathrm{~A}$ ). The $\mathrm{Cq}$ values corresponding to $10^{3}$ pGEM®-T-RPB1 copies were $33.69 \pm 1.2$. The $\mathrm{Tm}$ values of the amplified products from the assay with $10^{7}$ to $10^{3}$ pGEM ${ }^{\circledR}-\mathrm{T}$ RPB1 copies were $84.24 \pm 0.1{ }^{\circ} \mathrm{C}$ (Figure 3B). Therefore, the detection limit of the real-time PCR assay with RPB11 primer set for the sensitivity test of pGEM ${ }^{\circledR}-\mathrm{T}-\mathrm{RPB} 1$ was $10^{3}$ copies. The standard curves showed a dynamic linear range across at least $5 \log$ units of pGEM ${ }^{\circledR}-\mathrm{T}-\mathrm{RPB} 1$ copy number. Linear regression analysis revealed that the correlation coefficients $\left(R^{2}\right)$ were 0.976 with a slope value of 3.29, and the amplification efficiency $=101.55 \%$ (Figure 3C) These results showed an excellent linear correlation in the regression line and can be reliably used to calculate the target gene or Foc concentration.
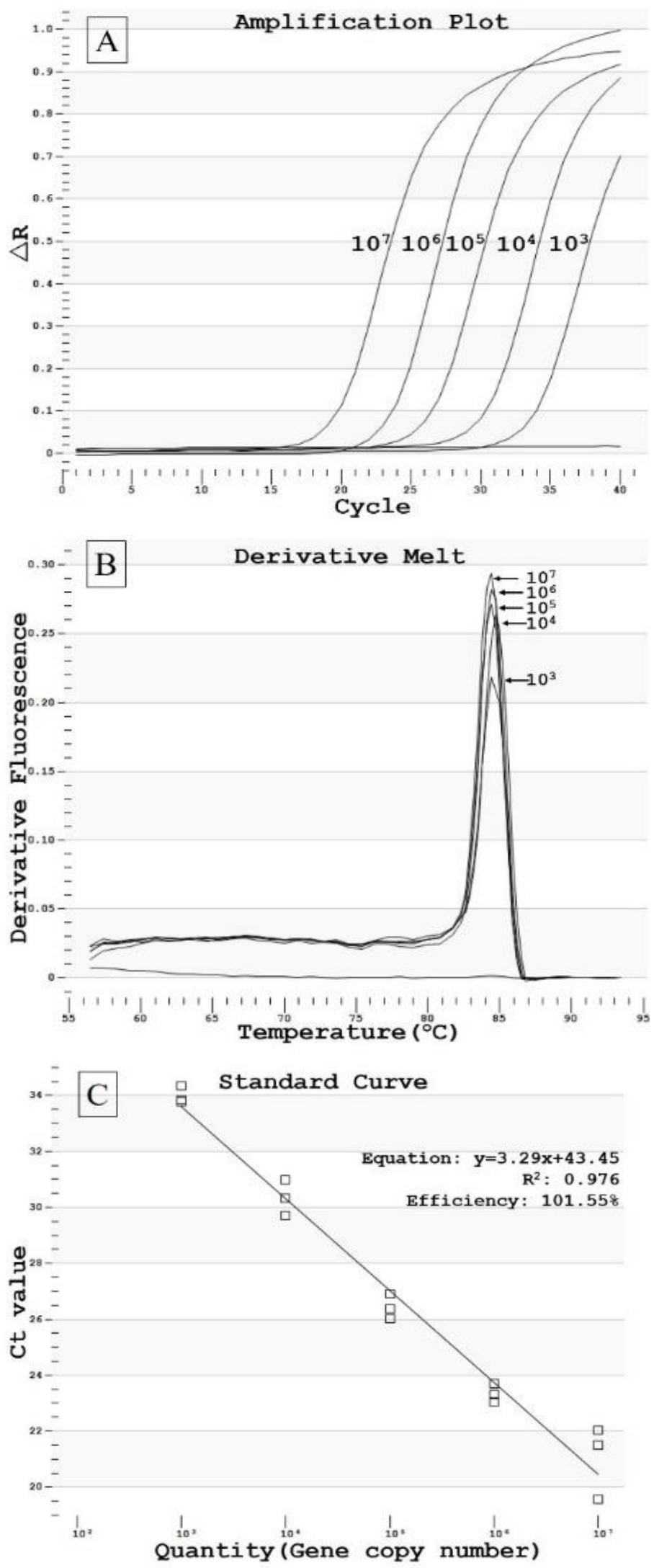

Figure 3 Sensitivity of the developed real-time PCR assay targeting RPB1 gene for Fusarium oxysporum f. sp. cubense detection. A: amplification signal, B: melting temperature, and C: standard curve. 


\section{Detection efficiency of the newly developed real-time PCR primers}

The detection efficiency of the developed real-time PCR assay using novel and published primers, and nested PCR assay were compared. Foc DNA at different amounts was used as a template for all assays. The results showed that the newly developed real-time PCR primers could detect the Foc DNA at a minimum of 5 pg. The $\mathrm{Cq}$ values were related to the amount of DNA template. The Tm values of all detected samples were $84.22 \pm 0.1{ }^{\circ} \mathrm{C}$. The detection efficiency was comparable to nested PCR developed by Prachaiboon et al. (2020) and real-time PCR developed by Yang et al. (2015) (Table 3).

Table 3 Detection efficiency of the developed real-time PCR assay targeting RPB1 gene and other published assays for Fusarium oxysporum f. sp. cubense detection.

\begin{tabular}{|c|c|c|c|c|c|}
\hline \multirow{3}{*}{$\begin{array}{l}\text { Foc } \\
\text { DNA } \\
\text { (pg) }\end{array}$} & \multirow{2}{*}{\multicolumn{2}{|c|}{$\begin{array}{c}\text { The developed real- } \\
\text { time PCR primers } \\
\text { (This study) }\end{array}$}} & \multicolumn{3}{|c|}{ Published assays } \\
\hline & & & \multirow{2}{*}{$\begin{array}{c}\text { Nested } \\
\text { PCR } \\
\text { (Prachaib } \\
\text { oon } \text { et al., } \\
\text { 2020) }\end{array}$} & \multicolumn{2}{|c|}{$\begin{array}{l}\text { Real-time PCR primers } \\
\text { (Yang et al., 2015) }\end{array}$} \\
\hline & $\mathrm{Cq}$ & $\operatorname{Tm}\left({ }^{\circ} \mathrm{C}\right)$ & & $\mathrm{Cq}$ & $\operatorname{Tm}\left({ }^{\circ} \mathrm{C}\right)$ \\
\hline 50000 & $14.73 \pm 0.34$ & 84.3 & + & $14.95 \pm 0.06$ & 82.5 \\
\hline 5000 & $19.79 \pm 0.18$ & 84.2 & + & $19.05 \pm 0.03$ & 82.4 \\
\hline 500 & $23.24 \pm 0.02$ & 84.3 & + & $26.59 \pm 0.44$ & 82.4 \\
\hline 50 & $29.67 \pm 0.12$ & 84.1 & + & $30.64 \pm 0.2$ & 82.5 \\
\hline 5 & $33.69 \pm 1.22$ & 84.2 & + & $34.19 \pm 0.8$ & 82.3 \\
\hline 0.5 & - & - & - & - & - \\
\hline
\end{tabular}

To evaluate the efficiency of the newly developed real-time PCR assay for detecting Foc in the symptomless banana suckers, a total of 10 sucker samples were tested using novel RPB11F/RPB11R primers and the other assays mentioned above. Seven out of ten samples showed a positive amplification signal based on novel RPB11F/RPB11R primers (Figure 4A), published Foc1 0422F1/Foc1-0422R1 primers (Yang et al., 2015) (Figure 4B), and nested PCR assay (Prachaiboon et al., 2020) (Figure 4C). The positive control samples, Foc isolate FOC1708, and infected parent bananas showed positive signals in al assays. The negative control samples did not generate a signal in any assays. Foc positive samples were detected by our assay and also the others (Figure 4). All assays presented the results in the same way.

Amplification Plot

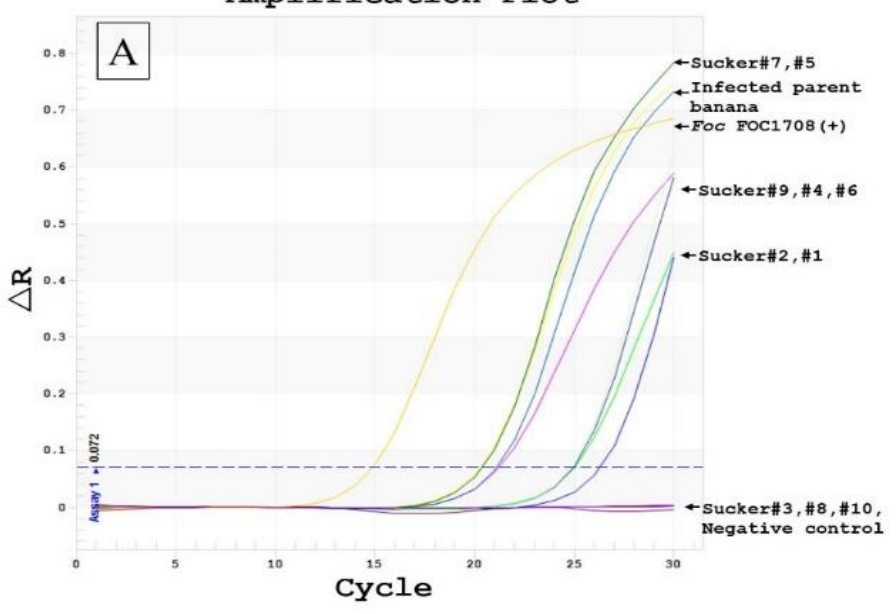

Amplification Plot

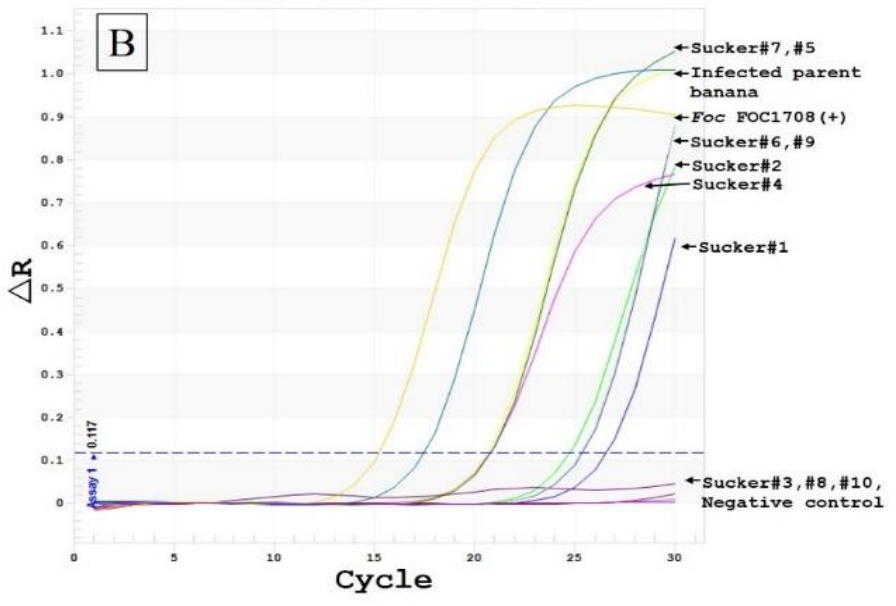

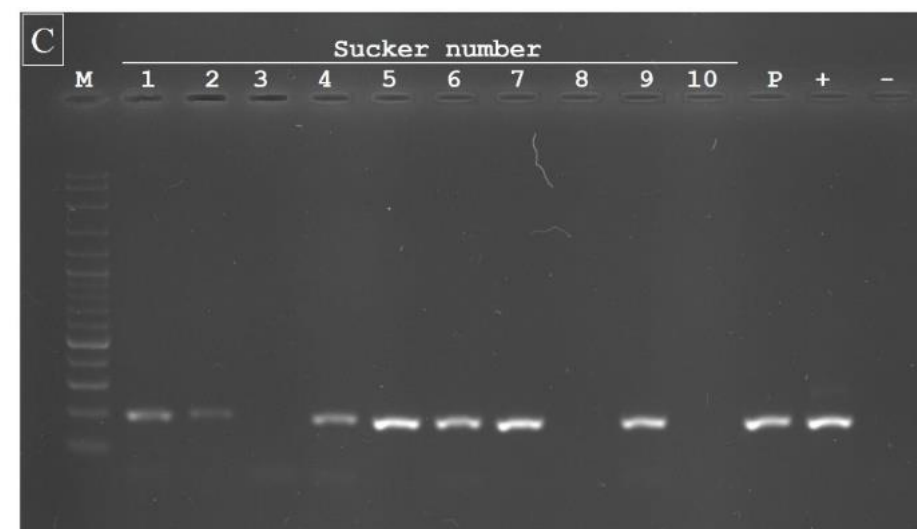

Figure 4 Detection of Fusarium oxysporum f. sp. cubense in banana sucker derived from infected parent plants. A: The developed real-time PCR assay targeting the RPB1 gene. B: Real-time PCR assay with primers developed by Yang et al. (2015) and C: Nested PCR assay (Prachaiboon et al., 2020), P infected parent banana, positive control (+): Foc isolate FOC1708, and negative control (-): non-infected banana.

\section{DISCUSSION}

Fusarium wilt or Panama disease of banana caused by Foc is a significant disease for banana production worldwide. The SYBR green-based real-time PCR assay in this finding provides an accurate and efficient assay for the Foc detection in the infected and symptomless banana suckers.

The SYBR green-based real-time PCR assay we developed for the Foc detection uses the specific primers designed based on the partial sequence of the new target gene $R P B 1$, the large subunit of RNA polymerase II. This gene plays a vital role in the initiation and elongation of mRNA (Roeder, 1996) and is commonly used to be a marker gene for Fusarium phylogenetic analysis in addition to other conserved regions (O'Donnell et al., 2010; O'Donnell et al., 2013; Maryani et al., 2019). In addition, RPB 1 is highly conserved within fungal species and successfully used to design specific primers in several fungi such as Colletotrichum truncatum (Tian et al., 2017), Penicillium italicum (Chen et al., 2019), etc. The partial RPB1 gene sequences of our Foc samples and Foc sequences from NCBI provided a potential sequence for designing a specific primer for $F o c$.

The newly developed RPB11 primer set generated positive amplification signals from isolates belonging to Foc race 1 and TR4. The $\mathrm{Cq}$ values of Foc race 1 isolates were less than $\mathrm{Cq}$ values of Foc TR4 because of the low concentration of DNA template. We found the difference between Tm of amplification products of Foc race 1 and TR4. This was because the G-C content of the target RPB1 region between Foc race 1 and TR4 may be different same as the finding of Matthews et al. (2020) reported that the melting point of target amplicons, the DNAdirected RNA polymerase III subunit beta $(R P C 2)$, are related to their race. From our result, we can use this finding to improve our assay further to clearly distinguish Foc race through High-Resolution Melting (HRM) analysis (Ratti et al., 2019; Schiwek et al., 2020)

The comparison of detection efficiency between the newly developed primers, the published primers, and the nested PCR assay confirmed that the SYBR based real-time PCR with the new primers was comparable to SYBR real-time PCR with primers published by Yang et al. (2015) and the nested PCR developed by Prachaiboon et al. (2020). The newly developed SYBR green real-time PCR assay could detect $F O c$ in material propagation, especially banana suckers, one of the most critical factors for disease dissemination (Ploetz, 2005; Dita et al. 2010; Pérez-Vicente et al., 2014). Foc is transmitted from infected mother plants to suckers which are usually symptomless (Stover, 1962). Three symptomless banana suckers did not generate any positive signal tested by all assays from our experiment, although the samples were collected from the symptom mother plant. We assume that Foc inoculum had not translocated to the new suckers yet, or the inoculum concentration was lower than the detection limit of our assay.

\section{CONCLUSION}

The novel real-time PCR primers, RPB11F and RPB11R, were designed from $R P B 1$ gene. Optimized SYBR green-based real-time PCR with the new primers is Foc specific detection assay. The sensitivity and efficiency of detecting target pathogens in a symptomless banana sucker were comparable to the published real-time PCR primers and the nested PCR assay. This developed assay will be a compelling choice for disease-free propagating materials screening and disease quarantine procedures.

Acknowledgments: This research is supported in part by the Graduate Program Scholarship from The Graduate School, Kasetsart University and The Faculty of Natural Resources and Agro-Industry, Kasetsart University Chalermphrakiat Sakon Nakhon Province Campus. 


\section{REFERENCES}

Aguayo, J., Mostert, D., Fourrier-Jeandel, C., Cerf-Wendling, I., Hostachy, B., Viljoen, A., \& Ioos, R. (2017). Development of a hydrolysis probe-based realtime assay for the detection of tropical strains of Fusarium oxysporum f. sp. $\begin{array}{lllll}\text { cubense } & \text { race } & \text { PLoS One, 12(2), e0171767. }\end{array}$ https://doi.org/10.1371/journal.pone.0171767

Bentley, S. B. K. G., Pegg, K. G., Moore, N. Y., Davis, R. D., \& Buddenhagen, I. W. (1998). Genetic variation among vegetative compatibility groups of Fusarium oxysporum f. sp. cubense analyzed by DNA fingerprinting. Phytopathology, 88(12), 1283-1293. https://doi.org/10.1094/PHYTO.1998.88.12.1283

Buddenhagen, I. (2009). Understanding strain diversity in Fusarium oxysporum $\mathrm{f}$. sp. cubense and history of introduction of 'Tropical Race 4' to better manage banana production. Acta Horticulturae, (828) 193-204 https://doi.org/10.17660/ActaHortic.2009.828.19

Chen, K., Tian, Z., Jiang, F., \& Long, C. A. (2019). Development of Penicillium italicum-specific primers for rapid detection among fungal isolates in citrus. Journal of microbiology and biotechnology, 29(6), 984-988. https://doi.org/10.4014/jmb.1904.04021

Czislowski, E., Fraser-Smith, S., Zander, M., O'Neill, W. T., Meldrum, R. A., Tran-Nguyen, L., Batley, J., \& Aitken, E. (2018). Investigation of the diversity of effector genes in the banana pathogen, Fusarium oxysporum f. sp. cubense, reveals evidence of horizontal gene transfer. Molecular plant pathology, 19(5), 1155-1171. https://doi.org/10.1111/mpp.12594

Dita, M. A., Waalwijk, C., Buddenhagen, I. W., Souza Jr, M. T., \& Kema, G. H. J. (2010). A molecular diagnostic for tropical race 4 of the banana fusarium wilt pathogen. Plant Pathology, 59(2), 348-357. https://doi.org/10.1111/j.13653059.2009.02221.x

Dita, M., Barquero, M., Heck, D., Mizubuti, E. S., \& Staver, C. P. (2018) Fusarium wilt of banana: current knowledge on epidemiology and research needs toward sustainable disease management. Frontiers in plant science, 9, 1468 https://doi.org/10.3389/fpls.2018.01468

Hall, T. A. (1999). BioEdit: a user-friendly biological sequence alignment editor and analysis program for Windows 95/98/NT. In Nucleic acids symposium series (Vol. 41, No. 41, pp. 95-98). [London]: Information Retrieval Ltd., c1979-c2000. Hofstetter, V., Miadlikowska, J., Kauff, F., \& Lutzoni, F. (2007). Phylogenetic comparison of protein-coding versus ribosomal RNA-coding sequence data: a case study of the Lecanoromycetes (Ascomycota). Molecular phylogenetics and evolution, 44(1), 412-426. https://doi.org/10.1016/j.ympev.2006.10.016

Koressaar, T., \& Remm, M. (2007). Enhancements and modifications of prime design program Primer3. Bioinformatics (Oxford, England), 23(10), 1289-1291. https://doi.org/10.1093/bioinformatics/btm091

Leslie, J. F., \& Summerell, B. A. (2008). The Fusarium laboratory manual. John Wiley \& Sons.

Li, C., Chen, S., Zuo, C., Sun, Q., Ye, Q., Yi, G., \& Huang, B. (2011). The use of GFP-transformed isolates to study infection of banana with Fusarium oxysporum f. sp. cubense race 4. European Journal of Plant Pathology, 131(2), 327-340. https://doi.org/10.1007/s10658-011-9811-5

Li, M. H., Yu, X. T., Wang, H. F., Zhou, J. N., Xi, P. G., \& Jiang, Z. D. (2012) Rapid detection and identification of Fusarium oxysporum $\mathrm{f}$. sp. cubense race and race 4. Scientia Agricultura Sinica, 45(19), 3971-3979. https://doi.org/10.3864/j.issn.0578-1752.2012.19.008

Lin, Y. H., Su, C. C., Chao, C. P., Chen, C. Y., Chang, C. J., Huang, J. W., \& Chang, P. F. L. (2013). A molecular diagnosis method using real-time PCR for quantification and detection of Fusarium oxysporum f. sp. cubense race 4 European Journal of Plant Pathology, 135(2), 395-405. https://doi.org/10.1007/s10658-012-0096-0

Lin, Y. H., Lin, Y. J., Chang, T. D., Hong, L. L., Chen, T. Y., \& Chang, P. F. L. (2016). Development of a TaqMan probe-based insulated isothermal polymerase chain reaction (iiPCR) assay for detection of Fusarium oxysporum f. sp. cubense $\begin{array}{lllll}\text { race } & \text { PLoS One, 11(7), } & & \end{array}$ https://doi.org/10.1371/journal.pone.0159681

Maryani, N., Lombard, L., Poerba, Y. S., Subandiyah, S., Crous, P. W., \& Kema, G. H. J. (2019). Phylogeny and genetic diversity of the banana Fusarium wilt pathogen Fusarium oxysporum f. sp. cubense in the Indonesian centre of origin Studies in Mycology, 92, 155-194. https://doi.org/10.1016/j.simyco.2018.06.003 Matthews, M. C., Mostert, D., Ndayihanzamaso, P., Rose, L. J., \& Viljoen, A (2020). Quantitative detection of economically important Fusarium oxysporum $\mathrm{f}$ sp. cubense strains in Africa in plants, soil and water. PloS one, 15(7), e0236110. https://doi.org/10.1371/journal.pone.0236110

O'Donnell, K., Sutton, D. A., Rinaldi, M. G., Sarver, B. A., Balajee, S. A. Schroers, H. J., ... \& Geiser, D. M. (2010). Internet-accessible DNA sequence database for identifying fusaria from human and animal infections. Journal of Clinical Microbiology, 48(10), https://doi.org/3708-3718.10.1128/JCM.00989-10 O’Donnell, K., Rooney, A. P., Proctor, R. H., Brown, D. W., McCormick, S. P., Ward, T. J., ... \& Geiser, D. M. (2013). Phylogenetic analyses of RPB1 and RPB2 support a middle Cretaceous origin for a clade comprising all agriculturally and medically important fusaria. Fungal Genetics and Biology, 52, 20-31. https://doi.org/10.1016/j.fgb.2012.12.004
Pérez Vicente, L. F., Dita, M., \& Martinez De La Parte, E. (2014). Technical Manual: Prevention and diagnostic of Fusarium Wilt (Panama disease) of banana caused by Fusarium oxysporum f. sp. cubense Tropical Race 4 (TR4) Proceedings of Regional Workshop on the Diagnosis of Fusarium Wilt (Panama disease) caused by Fusarium oxysporum f. sp. cubense Tropical Race 4 Mitigating the Threat and Preventing its Spread in the Caribbean, St. Augustine, Trinidad and Tobago, 05-09/05/2014.FAO, Rome, Italy. 74p.

Ploetz, R. C. (2005). Panama disease: an old nemesis rears its ugly head: part 1. the beginnings of the banana export trades. Plant Health Progress, 6(1), 18 https://doi.org/10.1094/PHP-2005-1221-01-RV

Ploetz, R. C. (2006). Fusarium wilt of banana is caused by several pathogens referred to as Fusarium oxysporum f. sp. cubense. Phytopathology, 96(6), 653656. https://doi.org/10.1094/PHYTO-96-0653

Prachaiboon, N., Thanyasiriwat, T., \& Kawicha, P. (2020). Detection of Fusarium oxysporum $\mathrm{f}$. sp. cubense in banana sucker by nested PCR technique. Proceedings of the 12th graduate research conference, 28/03/2020. Ubon Ratchathani Rajabhat University, Thailand. 732-738.

Ratti, M. F., Farrer, R. A., Cano, L. M., Faedda, R., \& Goss, E. M. (2019) Evaluation of high-resolution melting for rapid differentiation of Phytophthora hybrids and their parental species. Plant disease, 103(9), 2295-2304. https://doi.org/10.1094/PDIS-12-18-2291-RE

Roeder, R. G. (1996). The role of general initiation factors in transcription by RNA polymerase II. Trends in biochemical sciences, 21(9), 327-335 https://doi.org/10.1016/S0968-0004(96)10050-5

Schaad, N. W., \& Frederick, R. D. (2002). Real-time PCR and its application for rapid plant disease diagnostics. Canadian journal of plant pathology, 24(3), 250258. https://doi.org/10.1080/07060660209507006

Schiwek, S., Beule, L., Vinas, M., Pfordt, A., von Tiedemann, A., \& Karlovsky, P. (2020). High-resolution melting (HRM) curve assay for the identification of eight Fusarium species causing ear rot in maize. Pathogens, 9(4), 270. https://doi.org/10.3390/pathogens9040270

Stover, R. H. (1962). Fusarial wilt (Panama Disease) of bananas and other Musa species. Fusarial wilt (Panama disease) of bananas and other Musa species.

Stover, R. H. (1990). Fusarium wilt of banana: some history and current status of the disease. St. Paul, MN: APS Press.

Tajadini, M., Panjehpour, M., \& Javanmard, S. H. (2014). Comparison of SYBR Green and TaqMan methods in quantitative real-time polymerase chain reaction analysis of four adenosine receptor subtypes. Advanced biomedical research, 3 , 85. https://doi.org/10.4103/2277-9175.127998

Tian, Q., Lu, C., Wang, S., Xiong, Q., Zhang, H., Wang, Y., \& Zheng, X. (2017). Rapid diagnosis of soybean anthracnose caused by Colletotrichum truncatum using a loop-mediated isothermal amplification (LAMP) assay. European Journal of Plant Pathology, 148(4), 785-793. https://doi.org/10.1007/s10658-016-1132-2 Yang, L. L., Sun, L. X., Ruan, X. L., Qiu, D. Y., Chen, D. H., Cai, X. Q., \& Li, H. P. (2015). Development of a single-tube duplex real-time fluorescence method for the rapid quantitative detection of Fusarium oxysporum $\mathrm{f}$. sp. cubense race 1 (FOC1) and race 4 (FOC4) using TaqMan probes. Crop Protection, 68, 27-35. https://doi.org/10.1016/j.cropro.2014.11.004 